\title{
A capital breeder in a heterogeneous environment: lipid reserves and RNA:DNA ratio in Lake Baikal's endemic Epischura
}

Larry L. Bowman, Jr. ${ }^{\mathrm{a}, 1,2}$, Elizaveta S. Kondratieva ${ }^{\mathrm{b}, 2}$, Eugene A. Silow ${ }^{\mathrm{b}}$, Paul Wilburn ${ }^{\mathrm{c}}$, and Lev Y. Yampolsky,

${ }^{a}$ Department of Biological Sciences, East Tennessee State University, Johnson City, TN 37614.

${ }^{\mathrm{b}}$ Institute of Biology, Irkutsk State University, Irkutsk, Russia.

${ }^{c}$ Kellogg Biological Station, Michigan State University

*Corresponding author: yampolsk@etsu.edu

${ }^{1}$ Present address: Department of Ecology and Evolutionary Biology, Yale University, New Haven, CT 06520.

${ }^{2}$ These co-authors contributed equally to work.

Keywords: capital breeding, Epischura, lipids, RNA:DNA ratio, Baikal, zooplankton, life history 


\begin{abstract}
Lake Baikal (Siberia, Russia) is the oldest, the deepest and the most voluminous lake on Earth. During the last century, Baikal has experienced gradual increases in temperature but remains highly oligotrophic with increases in primary productivity limited to the warmest parts of the lake. Using whole body RNA:DNA ratio as an indicator of metabolic rate, we demonstrate that the key primary consumer in Baikal's plankton, Epischura baikalensis (Copepoda: Calanoida), is a capital breeder that relies on lipid storage to maintain productivity. In individuals from nature, the RNA:DNA ratio correlated with lipid content in samples from cold, low phytoplankton density locations from Baikal's North and Central basins, but not in samples from warmer South basin and Maloe More strait. Lipid reserves, both visually assessed and measured by Nile Red fluorescence, correlated positively with phytoplankton density. In laboratory experiments the RNA:DNA ratio responded to starvation and temperature in non-reproducing, low lipid storage females, but not in individuals with developed ovaries or high lipid storage. This indicates that, unlike many other zooplankton crustaceans, E. baikalensis uses resource storage to support current reproduction, which buffers the dependency of metabolic rate on current feeding conditions. We discuss possible effects of such buffering on E. baikalensis competition with non-endemic, largely income-feeding zooplankton species whose frequency is currently increasing in Baikal pelagia.
\end{abstract}




\section{Introduction}

Allocation of resources and energy into current growth, current reproduction and storage (i.e. future growth and reproduction) is the key life-history decision organisms need to make to maximize their reproductive output (Roff 1992, Stearns 1992). The opposite extreme strategies of such allocation are often termed income breeding (all reproduction is supported by current feeding) and capital breeding (all reproduction is supported from storage) (Drent and Daan 1980; Jönsson 1997; Stephens et al. 2009; Stephens et al. 2014). There is, of course, a continuum of intermediate strategies in between the two extremes; moreover, the same organism can be a capital or income breeder in different periods of its life cycle or both simultaneously with respect to different nutrients (see Stephens et al. 2014 for review). Which strategy is optimal depends largely on the seasonality of resource availability, organism lifespan and costs of resource storage (Sainmont et al. 2014; Stephens et al. 2014). The prevalence of capital or income breeders among species occupying pivotal niches may, conceivably, influence ecosystem productivity and stability in cyclic or unpredictable environments, because resources stored at a given trophic level during periods of high resource availability determine the flow of energy through the trophic levels during periods of resource scarcity.

The ratio between RNA and DNA concentration in tissues and whole-body samples has been widely used as a measure of metabolic rate and secondary production in aquatic animals. (Wagner et al. 1998; Gorokhova 2003; Chícharo \& Chícharo 2008; Holmborn et al. 2009; Gusmão \& McKinnon 2011; Tang et al. 2015; Foley et al., 2016). This measure is based on the assumption that, while DNA concentration per cell is usually 
constant, the amount of total RNA varies and reflects the intensity of transcription (affecting mRNA concentration) and translation (affecting rRNA concentration). Thus, higher RNA:DNA ratios indicate higher rate of protein biosynthesis and, by extension, higher metabolism and biomass production, including egg production. Clearly then, RNA:DNA ratio, as a proxy for egg production, would reflect current food availability only in cases of income breeding strategy when egg production is not buffered by any stored reserves.

In fish, the joint analysis of RNA:DNA ratio and lipid content revealed that the RNA:DNA ratio reflects current feeding conditions, while lipid content is more indicative of previous, long-term history of resource availability, including the abundance of maternally-supplied resources (Paulsen et al., 2014; Peters et al., 2015). In zooplankton crustaceans, several studies have demonstrated positive correlations between RNA:DNA ratio and egg production and current food availability (Saiz et al. 1998; Wagner et al. 1998; Speekmann et al. 2007; Holmborn and Gorokhova 2008; Ning et al. 2013). For several species, including cladocerans (Vrede et al. 2002) and copepods (Wagner et al. 2001), convincing calibration curves of RNA:DNA ratio to biomass production exist. Indeed, data on copepods often showing a rapid response of RNA:DNA ratio to current feeding conditions (e.g., Speekmann et al. 2007), suggest a tendency toward income breeding. Alternatively, in the case of pure capital breeding, the RNA:DNA ratio should correlate with individuals' resource storage and not with current feeding conditions.

While routine in marine zooplankton studies, the RNA:DNA ratio approach has not frequently been applied to freshwater zooplankton species (but see Bullejos 2014), which exist in much more seasonally and stochastically variable environments than their 
marine counterparts. These environments, especially for organisms with short lifespans yet slow development due to low temperatures, are conducive for capital breeding to evolve as a successful life history strategy (Varpe et al. 2009; Sainmont et al. 2014; Stephens et al. 2014). These observations suggest that in a joint analysis of RNA:DNA ratio and stored resources, in particular in freshwater zooplankton, one might expect to observe a buffering effect of stored resources on current RNA:DNA ratio.

Here we report the application of the RNA:DNA ratio approach to test the role of resource storage in the calanoid copepod Epischura baikalensis Sars in Lake Baikal (Siberia, Russia). Baikal is the oldest, deepest, and largest (by volume) lake on Earth. Its benthic communities contain extremely high levels of endemic biodiversity, including amphipod, gastropod, planarian and several other endemic species flocks (Kozhov 1963; Kozhova and Izmest'eva 1998). Baikal zooplankton is, to the contrary, quite species poor and distinctly deprived of cladocerans, at least until recent decades (Hampton et al. 2008; Izmest'eva et al., 2916). The depauperate assemblage and its unusual bias toward copepods were first noted by Georg Ossian Sars, the discoverer of the most common Baikal zooplankter - Epischura baikalensis (Sars 1900). Indeed, in most macrozooplankton samples from open Baikal, E. baikalensis constitutes 96-100\% of the total organism count, and it is responsible for nearly all secondary production in the open lake (Afanasyeva 1998; Melnik 1998). It is, therefore, a pivotal species for the Baikal's pelagic community (which is the component of the lake's ecosystem that is responsible for $95 \%$ of energy flow and $90 \%$ of matter turnover in the lake) and a key element of the food chain leading to endemic coregonid fishes and seals (Moore et al. 2009). Baikal Epischura undergoes two generations per year (Afanasyeva 1998) with the "winter- 
spring" generation reaching sexual maturity in mid-summer. Summer secondary

production in Epischura as well as its competition with non-endemic zooplankton species may therefore depend on the amount of resources accumulated during naupliar and copepodite larval studies in winter and spring and on current feeding conditions adults experience during summer months.

In the last 60 years Baikal has shown a significant increase in surface temperature, in particular in its South basin (Fietz et al., 2005; Hampton et al. 2008; Shimaraev et al., 2009; Shimaraev and Domysheva, 2013). At the same time, primary production remained low or even decreased throughout the lake, except, again, its South basin, where there has been an apparent increase in productivity (Izmest'eva et al., 2016). Additionally, the relatively shallow (depths below $200 \mathrm{~m}$ ) Maloe More strait that separates Olkhon island from the mainland differs from the rest of Baikal in being warmer and more productive (Fietz et al., 2005). Possibly as the result of gradual warming and eutrophication of Baikal's very cold, very oligotrophic waters, the frequency of other zooplankton species, such as cosmopolitan cladocerans (Daphnia and Bosmina) and cyclopoid copepods (Cyclops), previously restricted to shallow bays, has increased in open Baikal (Melnik et al. 1998; Hampton et al. 2008; Moore et al. 2009; Izmest'eva et al., 2016). Furthermore, the increase of cladocerans relative to the endemic E. baikalensis appears to be associated with the interplay between increased surface temperatures, reduced mixing, and changes in the vertical distribution of zoo- and phytoplankton (Hampton et al. 2014). RNA:DNA ratio may be instrumental in the analysis of long-term competitive interactions between fast-growing cladocerans with their rapid metabolic rate and slower-growing copepods (Bullejos et al. 2014). Because the productivity of $E$. 
baikalensis and the outcome of its competition with cladocerans is likely to be crucial for the composition of Baikal's pelagic community, a better understanding of this species' resource allocation strategy is of a significant interest for Baikal conservation ecology.

The goal of this study is to compare E. baikalensis from the warmer, less oligotrophic regions (South basin and Maloe More) with those from colder, highly oligotrophic regions (North and Central basins) with respect to the possible buffering effect of lipid reserves on productivity as measured by RNA:DNA ratio. We further test the observed relationships in starvation and temperature experiments under laboratory conditions.

\section{Materials and Methods}

\section{Sampling}

Epischura. baikalensis were collected in July-August 2013 by vertically towing a plankton net $($ mesh size $=80 \mu \mathrm{m}$; diam $=39 \mathrm{~cm})$ from the depth of $150 \mathrm{~m}$ to the surface and either immediately freezing animals in liquid nitrogen or transferring them to the laboratory for experiments. In mid-summer E. baikalensis population is composed of adult individuals born during winter-spring reproduction peak (Afanasieva, 1998) with the majority of the population occurring between 250-50m depths (Afanasieva, 1998) well below the thermocline (5-25 m). Samples were collected at 12 different locations throughout the lake, representing three open lake regions or basins of Baikal (North, Central and South) and the warmer, shallower Maloe More straight (Fig. 1A). Only Epischura from Station 1 (South basin, $2.8 \mathrm{~km}$ south from the Baikal Biological Station of Irkutsk State University 
at Bolshie Koty) were used for laboratory experiments, which should be kept in mind as possible limitation of the observed results, given a significant variation in RNA:DNA ratio and lipids content among stations (see below).

Phytoplankton abundance at each sampling location was quantified by chlorophyll $a$ readings made with vertical tows of a YSI sonde (6600 series) from $50 \mathrm{~m}$ (or from the bottom at depths less than $50 \mathrm{~m}$ ) to the surface and by direct counts of Lugol-preserved samples obtained by a Van Dorn bottle at the depth of $75 \mathrm{~m}$ (highest density of Epischura in summer is observed between 50 and $100 \mathrm{~m}$, Melnik 1998). For each sample, $1 \mathrm{~L}$ of whole water was preserved with Lugol's solution immediately upon collection, settled for 24 hours, decanted to $15 \mathrm{~mL}$, and $5 \mathrm{~mL}$ of each concentrated sample was counted in Utermöhl chambers at 400X, with the following categories of algal cells recognized: small dinoflagellate $(2 \mu \mathrm{m})$, medium dinoflagellate $(5 \mu \mathrm{m})$, Gymnodinium baicalense,

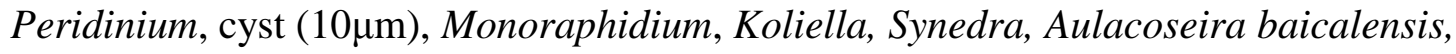
Dynobryon, Cyclotella minuta, Cyclotella baicalensis, picoplankton $(1 \mu \mathrm{m})$, unidentified green eukaryote $(3 \mu \mathrm{m})$, Anabaena.

Additionally, in order to provide a rough classification of the samples into those taken at historically warmer vs. historically colder areas, each sample was characterized by multiyear averages of temperatures at the surface, 10 and $50 \mathrm{~m}$ from the nearest 1-3 stations available from Limnological Institute Baikal Water Temperature database (Shimaraev et al., 2009; M.N.Shimaraev, personal communication). Stations from the South+Maloe More region are well separated from North+Central region on the plane of the two principal components (together explaining $74.2 \%$ of variance) calculated on the basis of in-situ and long term temperature data, chlorophyll concentration in 0-50 m layer, 
depth of deep chlorophyll maximum, total phytoplankton count and phytoplankton count excluding picoplankton (Fig. $1 \mathrm{~B})$.

We do not have temperature profile or phytoplankton count data for one of the North basin stations, and we do not have lipid quantification, due to low number of preserved individuals, in one of the South basin samples. These samples are excluded from the analyses involving these variables, but are included in the comparison between RNA:DNA ratio and multi-year temperature data.

\section{Lipid content and ovary development scores}

To visually assess lipid content in life or liquid nitogen-preserved individuals, $E$.

baikalensis females were split into the following arbitrarily defined classes: Lipid content: “0” - no lipid vesicles visible; "1" - lipid vesicles visible but spaced out; "2" - lipid vesicles packed tightly and occupy about $1 / 2$ of the cephalothorax length and " 3 " a single large lipid vesicle visible occupying $2 / 3$ or more of the cephalothorax length. In order to confirm that this scoring adequately reflects lipids content, lipid content was quantified in groups of individuals with the same lipid score following Alonzo and Mayzaud, 1999, with modifications. Specifically, 5-50 liquid nitrogen-preserved adult females were weighted for wet weight (up to $10 \mu \mathrm{g}$ precision) homogenized together in $200 \mu \mathrm{L}$ of deionized water and centrifuged for $3 \mathrm{~min}$ at $8,000 \mathrm{rpm}$. $90 \mu \mathrm{L}$ aliquots of the supernatant were first measured as blanks at $485 \mathrm{~nm}$ excitation/590 nm emission in a black 96-well plate on a BioTek plate reader, after which $10 \mu \mathrm{L}$ of $2 \mu \mathrm{g} / \mathrm{mL}$ Nile Red (Sigma-Aldrich) solution in acetone was added to each well, incubated for 30 minutes and measured again at the same wavelengths. Non-polar lipids calibration was obtained in the same conditions 
with wells contacting from 0 to $0.2 \mu \mathrm{g}$ TAG 17:0 standard (Sigma-Aldrich) per well. Lipid content in TAG 17:0 equivalents per mg wet weight was then determined according to the equation

$L(\mu \mathrm{g})=0.08\left(F L_{485 / 590}-F L_{485 / 590, \text { blank }}\right)-46$

(linear from 5-450 $\mu \mathrm{g}$ per well, $\mathrm{R}^{2}=0.99$; Electronic Supplementary Material (ESM Fig. S1).

We further quantified lipid content by fluorescent microscopy with the same fluorophore (see ESM Figure S1 for details). Both the fluorometry and fluorescent microscopy lipid content measurements support visual scores as an adequate semi-quantitative measure, with some saturation between classes "2" and "3" (ESM Figure 1). Only a few individuals with lipid score 0 were observed in the laboratory experiments, so for the purpose of this analysis they were lumped together with lipid score 1.

Similarly, ovary development stage was assessed as one of 3 classes: "0" - no visible ovaries; "1" - ovaries detectable as nearly transparent elongate structures; "2" ovaries clearly visible as dark structures occupying over $3 / 4$ of the cephalothorax length (Fig. 2). This scoring is not possible on frozen or ethanol-preserved specimens, as ovaries are no longer clearly visible, so all analyses involving ovaries scores include only live animals. When, on a few occasions, an individual was recorded carrying the egg sack, its ovaries score was recorded as "2", assuming that this correctly reflects both the reproductive status and the expected RNA:DNA ratio, as any bias in RNA:DNA ratio the biomass of eggs can introduce, will occur regardless of whether the eggs are still in the ovaries or already in the external egg sack. 


\section{RNA and DNA extraction and determination}

Frozen or living individual adult female Epischura were homogenized in $25 \mu \mathrm{L}$ of $50 \mathrm{mM}$ TE buffer, pH 8.0 containing $60 \mathrm{mAU} / \mathrm{ml}$ proteinase K (Qiagen). Proteinase K, rather than N-laurylsarcosine extraction that follows Kaplan et al (2001) protocol was chosen due to greater RNA stability during the 20-40 min window following extraction (ESM Figure S2), in contrast to McGinty et al., 2008. Homogenates were vortexed briefly and incubated for $20 \mathrm{~min}$ in a $54^{\circ} \mathrm{C}$ water bath, with periodic vortexing. After the incubation, samples were centrifuged for 6 minutes at $10,000 \mathrm{~g}$, and $10 \mu \mathrm{L}$ supernatant aliquots were used for fluorescence determination of RNA and DNA using a Qubit fluorometer and Qubit high sensitivity dsDNA and broad range RNA assay kits (ThermoFisher Scientific). Measurements were conducted at $20^{\circ} \mathrm{C}$ according to the manufacturer's protocol. The dyes used in these procedures allow sufficient sensitivity to measure RNA and DNA in individual microcrustaceans (McGinty et al. 2008). In order to be able to compare estimates obtained from fresh and frozen individuals, we compared RNA concentration, DNA concentration and RNA:DNA ratio measured in frozen and live specimens taken from the same net tow and found no significant differences (ESM Table S1). Because the quantities of of RNA and DNA that we were able to extract from single Epischura females allow just one measurement of each nucleic acid, measurements from each adult were taken without replication, so individuals were the units of replication in comparison among samples or laboratory treatments. Replicated measurements from single individuals require reduced aliquot volumes, resulting in lower measurement precision. Individuals from several different stations were analyzed in each batch of measurements to reduce confounding with differences between batches. 


\section{Laboratory experiments}

E. baikalensis females were quickly transported to the laboratory and placed in a $5^{\circ} \mathrm{C}$ incubator (the temperature similar to that of summer hypolimnion in Baikal) and sorted and counted within 6 hours of sampling. RNA:DNA ratio measurements in individuals from the same sample not used in the laboratory experiments served as the shared "sample" control for both fasting and temperature exposure experiments. For the fasting treatment, 100 adult females were placed into each of six jars containing $3 \mathrm{~L}$ of Baikal water filtered through a $0.2 \mu \mathrm{m}$ filter. Three of these jars served as a control and were fed ad libitum by adding Cryptomonas erosa culture daily to a final concentration of 12,000 cells $/ \mathrm{ml}$. The other three jars remained unfed and constituted the fasting treatment. The experiment lasted for 7 days. On day 7, individuals were removed, scored for ovary developmental stage and fat content, and used in RNA:DNA measurements. For “temperature exposure," 100 adult females were placed into each of twelve jars each containing $3 \mathrm{~L}$ of filtered Baikal water and placed into either 5,10 , or $15^{\circ} \mathrm{C}$ incubators (4 replicate jars per temperature). As in the fed control of the fasting experiment, C. erosa was added to all jars daily to the final concentration of 12,000 cells/ml. After 10 days, surviving females were counted, scored as above, and used in RNA:DNA measurements. Recovery of individuals from the jars in 5,10 , or $15^{\circ} \mathrm{C}$ treatments was 66,49 and $28 \%$, respectively. These numbers reflect, in addition to some individuals not recovered for random reasons, increased mortality at higher-than ambient temperatures similar to estimates of Epischura mortality in other laboratory studies (T. Ozersky, University of Minnesota Duluth, personal communication). Recovery rate from the $5^{\circ} \mathrm{C}$ is consistent 
with the life expectancy of the "winter-spring" generation of E. baikalensis in midsummer (Afanasyeva 1998).

Because in both experiments, the RNA:DNA ratio and the lipids and ovaries scores were measured after the laboratory treatment, their comparison reflects the laboratory conditions, not the previous history. For example, at least some individuals with ovaries score 0 recorded after a laboratory treatment have entered the lab with fully developed ovaries and produced a clutch and shed the egg sack during the experiment (ESM Table S2 for the data).

\section{Data analysis}

All statistical analyses were performed using JMP 10 (SAS Institute 2010). RNA:DNA ratio was square root transformed for normality in all analyses. Differences between regions $(\mathrm{S}+\mathrm{M}$ vs. $\mathrm{N}+\mathrm{C})$ in average lipid score and RNA:DNA ratio were analyzed by nested ANOVA with stations nested within regions. The correlation between individuals' lipid score and RNA:DNA ratio in the two regions was analyzed by heterogeneity of slopes analysis with the region and the main effect and lipid score as a covariate.

Laboratory treatments were analyzed by means of REML ANOVA (SAS Institute, 2010) with square root transposed RNA:DNA ratio as the response variable and either "feeding treatment" or "temperature treatment" as a fixed effect and the "jar" as a random effect nested within the treatment effect. We first analyzed this model for subsets of individuals with each ovary development score or lipid content score. Then either of these scores was added to the model as a fixed effect for a joint analysis. In such overall analysis, the wildcaught animals from the same site on the same or a close date were used as a control, serving as one of the levels of the treatment effect and shared by both experiments. The 
random factors in this analysis included the jar effect, the score-by-jar interaction and the residuals; the denominator degrees of freedom used are based on an approximation to the distribution of the statistic obtained when the fixed effects' covariance matrix, adjusted using the Kenward-Roger correction (Kenward and Roger, 1997; SAS Institute, 2010). Individual combinations of treatment and ovaries/lipids score levels were compared by Tukey test (alpha $=0.05$ ). This analysis assumes that there is no interaction between ovary development state and lipid content in the effects of RNA:DNA ratio. We could not test whether such interactions exist, because not all combinations of ovary development score and lipid content score were observed in all jars. In select treatments in which all combinations were observed, there is no evidence of such an interaction (data not reported).

Interpreting ratios can be difficult; in order to understand whether the observed changes in RNA:DNA ratio are due to changes of RNA content at the background of constant DNA content or to differences in DNA content not accompanied by changes in RNA or to a combination thereof, we also report individual changes in DNA and/or RNA content (ESM Figure S3).

\section{Results}

The frequencies of individuals with different lipid and ovaries scores in sample SB3 and the laboratory experiment and the frequencies of individuals with different lipid scores across all samples, as well as the contingency table analysis for each of the tables are presented in ESM Table S2. The feeding/fasting treatment had no effect on the distribution of either lipids or ovaries scores, while the temperature experiment resulted in 
the decline of the frequency of high lipid scores in all treatments relative to wild-caught controls (indicating that lipid reserves were being used during the experiment) and in the decline of the frequency of individuals with higher ovaries scores in the $15^{\circ} \mathrm{C}$ treatment (indicating that some individuals produced a clutch and shed the egg sack during the course of the experiment). Lipid and ovaries scores co-occurred nearly uniformly with, unsurprisingly, a slight underrepresentation of the highest ovaries score among individuals with the lowest lipids scores. There was a significant heterogeneity in lipid scores frequencies among samples with the largest differences observed between the North and the South stations.

Warmer stations had higher phytoplankton count (Fig. 3 A) and two Maloe More samples from the highest phytoplankton count stations also had the highest Nile redmeasured lipid content (Fig. 3B). Consistently, there was a significant difference in lipid scores among stations (Table 1, ESM Table S2), but the difference among regions was not significant. There was, on the other hand, a significant difference in RNA:DNA ratio between the two regions compared relative to stations nested within regions (Table 1, Fig. 3C), with Epischura from colder, oligotrophic North and Central basins showing lower RNA:DNA ratio than warmer South basin and Maloe More. Both DNA and RNA content were lower in samples from historically warmer locations (ESM Fig. S3A, B), probably indicating that animals were smaller in such samples, but DNA content change was steeper, resulting in the observed higher RNA:DNA ratio.

There was no indication of correlation either across or within regions between RNA:DNA ratio and in-sample phytoplankton counts (Fig. 3 D) or chlorophyll measurements (data not shown). 
Individual's lipid score positively correlated with RNA:DNA ratio in individuals from North and Central basins, but not in South basin or Maloe More (Fig. 4). Heterogeneity of slopes was significant with $\mathrm{P}<0.0024$ (Table 2). Thus, E. baikalensis females sampled from nature show patterns consistent with capital breeding strategy, i.e. RNA:DNA ratio does not correlate with current feeding conditions. However, RNA:DNA ratio does correlate with lipid reserves in individuals from populations where average RNA:DNA ratio is low, but not from populations where average RNA:DNA ratio is high. This difference is consistent with the long-term data indicating low primary production within North and Central basins.

\section{Fasting experiment}

Consistent with the data from field populations, the effect of fasting on RNA:DNA ratio was not significant for any of the subsets of individuals with different lipid scores (Fig 5A) except the difference between wild-caught controls and lab-fasting individuals with the intermediate lipid score (Tukey test $\mathrm{P}<0.05$ ). In the overall analysis with lipid score as a factor, the effect of feeding became moderately significant $(\mathrm{P}<0.018$, Table 3$)$. On the other hand, RNA:DNA ratio was significantly lower in starved than in fed nonreproducing individuals (ovaries score 0, Fig. 3C; $\mathrm{F}=12.8$; df num=1; df den=4; $\mathrm{P}<0.013$ in a within ovaries class ANOVA). No such differences were observed for individuals with ovaries scores 1 and $2(\mathrm{P}>0.5$ and $\mathrm{P}>0.47$, respectively). In the joint analysis, the ovaries effect was significant (Table 3); and, although the ovaries-by-feeding interaction was not significant $(\mathrm{P}<0.118)$ when tested against the random ovaries-by-jar nested effect, the Tukey test reveals that the difference between reproducing and non-reproducing 
individuals was significant only for the unfed, but not in fed or wild-caught control individuals. In other words, females with no visible ovaries reduced their RNA:DNA ratio in response to fasting, while the ones with visible ovaries did not (Fig. 5C).

\section{Temperature experiment}

In the joint analysis of temperature treatment and lipid scores the only classes of individuals different from each other were the $5^{\circ} \mathrm{C}$ vs. $15^{\circ} \mathrm{C}$-acclimated individuals with lipid score 0 . These females demonstrated over two-fold reduction of RNA:DNA ratio after 10 days of acclimation to $15^{\circ} \mathrm{C}$ relative to either wild-caught females or females kept in the laboratory at $5^{\circ} \mathrm{C}$ (Fig. 5B). The temperature effect was moderately significant $(\mathrm{P}<0.014$, Table 3), with no indication of the interaction effect. In the analyses conducted separately for subsets of individuals with different ovaries scores there was a significant decrease of RNA:DNA ratio with increasing temperature among non-reproducing individuals $\left(\mathrm{F}=7.61\right.$; $\mathrm{df} \_n u m=2$; $\left.\mathrm{df} \_\mathrm{den}=9 ; \mathrm{P}<0.011\right)$, but not among individuals with ovaries scores 1 or $2(\mathrm{P}>0.17$ and $\mathrm{P}>0.8$, respectively). In the joint analysis of the model incorporating the ovaries scores, these scores were the only significant fixed effect (Table

3) with Tukey test suggesting that the only classes different from each other were, individuals with ovaries scores 0 vs 2 in the $15^{\circ} \mathrm{C}$ temperature treatments (Fig. 5D). In other words, the non-reproducing individuals reduce their RNA:DNA ratio during exposure to high temperature greater than the reproducing ones.

The changes in RNA:DNA ratio observed in the fasting and temperature experiments were due to changes in RNA content, while the DNA content did not change much (ESM Fig. S3 C,D), as expected in a short-term experiment with little somatic 
growth occurring. None of the DNA content comparisons are significant in Tukey tests $(\mathrm{P}>0.05)$.

\section{Discussion}

We demonstrate that, in both natural populations and in laboratory-acclimated individuals of the Lake Baikal endemic and cryophilic stenotherm Epischura biakalensis, the effects of feeding conditions and temperature on the whole-body RNA:DNA ratio are highly dependent on females' lipid storage. In natural populations sampled from warmer regions with higher average primary productivity, RNA:DNA ratio is high and is not dependent on lipid storage. In populations sampled from colder, more oligotrophic regions the RNA:DNA ratio is lower and increases with lipid score. Similarly, seven day fasting results in a reduction of RNA:DNA ratio for low-lipid, non-reproducing individuals, while there is no such reduction (either in comparison with fed treatment or with the wild-caught control) in individuals with high lipid scores and fully developed ovaries (Fig. 5 A, C). In other words, we observed patterns consistent with the hypothesis of capital breeding strategy employed by E. baikalensis females, where individuals rely on resource storage for reproductive investment.

Additionally, the exposure to elevated temperature close to the upper tolerance limit $\left(15^{\circ} \mathrm{C}\right)$ caused a 2 -fold drop in RNA:DNA ratio in females with no visible ovaries, likely indicating reduction in metabolic activity and growth. This effect, however, is not observed in females with fully developed ovaries (Fig. 5). Although $15^{\circ} \mathrm{C}$ is below the optimum for many freshwater copepods, it is a stressful and nearly lethal temperature for 
Baikal's Epischura (T.Ozersky, University of Minnesota Duluth, unpublished data). This observation can be interpreted as an indication of reduced metabolic activity in a stressful environment. However, this effect is, again, virtually non-existent in females with fullydeveloped ovaries (Fig. 5D), regardless of their lipid reserves (Fig. 5B). Thus, individuals currently investing resources into provisioning ovaries are capable of doing so at a constant high rate regardless of current food availability or presumed temperaturemediated basal metabolism demands. Non-reproducing individuals, in contrast, show lower RNA:DNA ratios that do respond to current environmental conditions, again, consistent with the hypothesis of capital breeding in E. baikalensis females.

It is worth noting that E. baikalensis appears to be a capital breeder, but "income sustainer", as non-reproducing individuals do respond to fasting and high temperature. It is difficult to know whether the individuals with no visible ovaries are skipping a clutch, ceasing reproduction altogether due to senescence or are simply at the very beginning of the next ovarian cycle. It does appear, however, that storage-mediated buffering of metabolic rate measured as RNA:DNA ratio only occurs when there is a commitment for provisioning eggs in fully developed ovaries.

In should be noted that this analysis was conducted under the assumption that there is no interaction between the lipid score and ovaries scores on the RNA:DNA ratio, as the effect of both scores could not be analyzed together. It is conceivable that the effects of high lipid scores and high ovaries scores are non-additive, and the main effects we observed may be biased by such interaction, particularly given that high lipid scores tended to slightly co-occur with high ovaries scores. This uncertainly remains an important caveat in our data interpretation. 
This observation notwithstanding, one consequence of these results is that it appears that RNA:DNA ratio cannot be used as an indicator of current feeding conditions in the population of E. baikalensis without individuals' lipid content and reproductive status taken into account. Any possible buffering effects of nutrient storage may eliminate such direct effects, while demographic differences among populations (portions of females with fully-developed ovaries) may account for the inter-population differences in RNA:DNA ratio. The observed overall strong effect of ovaries development score on the RNA:DNA ratio should be taken as a possible caveat in any interpretation of this parameter as a measure of current feeding conditions. Many such calibrations have been obtained in laboratory conditions only and usually without individuals' reproductive status taken into account (Wagner et al. 1998; Wagner et al. 2001 Speekmann et al. 2007). In any organism in which females produce eggs that are large relative to body mass, the degree of ovary development is certain to affect whole-body RNA:DNA ratio, as nutritionally-rich eggs possess significantly more cytoplasm (and thus, mRNA and rRNA) than somatic tissues do. Thus, in organisms with large egg size and little somatic growth in adults, RNA:DNA ratio may reflect commitment to secondary production in the form of egg provisioning, often regardless of current resource availability. This conclusion corroborates the growing consensus that RNA:DNA ratio should be used only when sources of background variation can be accounted for (Foley et al., 2016)

Most of previous RNA:DNA ratio studies in copepods were limited to tropical or temperate marine species. These studies implicitly assumed income breeding strategy in the studied species or demonstrated it by showing fast response in both egg production and RNA:DNA ratio to changes in laboratory-controlled feeding and/or temperature 
conditions (Gorokhova 2003; Speekmann et al. 2007; Gusmão, McKinnon 2011). In contrast, studies of high-latitude species that inhabit cold waters with a short feeding season concluded that a significant portion of egg biomass is provisioned by capital breeding, i.e. from storage. (Hagen, Schnack-Schiel 1996; Varpe et al. 2009). Hagen and Schnack-Schiel (1996) in particular, found that lipid storage in an Antarctic copepod, while necessary to survive winter diapause, is also used to supply nutrients for egg production. We find it therefore not surprising that we observe the same in Lake Baikal Epischura that spends nearly its entire life in the hypolimnion with constant $4{ }^{\circ} \mathrm{C}$ temperatures and also undergoes diapause.

Coupling between early season primary production and late-season secondary production in seasonally variable lakes is one of the understudied questions in freshwater ecology (Hampton et al., 2015). What does the conclusion about Epischura's capital breeding strategy mean for the understanding of plankton ecology in Baikal, where a significant portion of primary production occurs during winter and spring months (Straskrabova et al., 2005; Katz et al., 2015)? Clearly, buffering secondary production by lipid reserves makes Epischura less dependent on current primary production and couples summer secondary production with the late winter primary production and vise versa. Epischura undergoes two generations per year in Baikal (Afanasyeva 1998): the winterspring generation that hatches as nauplii in January-March and reaches maturity in JuneAugust and the summer generation that hatches in July-August and reaches maturity in winter under ice. Assuming the patterns observed here indeed indicate capital breeding, the egg production in each generation reflects feeding conditions throughout the entire females' development time several months prior to the peak of egg production. 
On the other hand, we observed higher and lipid storage-independent RNA:DNA ratio in the warmer areas of the lake, South basin and Maloe More. At least for South basin there is also evidence that primary production has been increasing over the last several decades (Izmest'eva et al., 2016). As only about 15\% of water volume is exchanged per year between each basin (Verbolov, 1996), the majority of Epischura sampled on a particular date has likely experienced only local feeding conditions throughout its lifetime. It appears that in these areas E.baikalensis secondary production may be saturated due to higher phytoplankton density and does not reflect previous feeding conditions. Further warming and eutrophication of Baikal may therefore loosen the between-season coupling between primary and secondary production.

Buffering reproductive efforts by resource storage makes Epischura less dependent on current feeding conditions and possibly allows it to sustain reproduction during summer phytoplankton depression, something that may be difficult for cosmopolitan zooplankton, particularly cladocerans, as they enter Baikal's main body from warmer, more eutrophic bays. Such advantages of the endemic species over invading cosmopolitan species may disappear as summer and fall primary production continues to increase as it has during the last several decades (Hampton et al. 2008; Moore et al. 2009; Izmest'eva et al. 2016), particularly in the South basin. We do not have data on RNA:DNA ratio in cosmopolitan zooplankton invading Baikal, so it is difficult to estimate their reproductive success at times of low primary production. Paradoxically, it is the colder, oligotrophic North basin where cosmopolitan zooplankton species seem to be increasing in density (Izmest'eva et al., 2016). One possible explanation for this is that the main source populations of cosmopolitan zooplankton in Baikal is the shallower and 
warmer Chivyrkuj Bay located upstream from North basin in terms of prevailing counterclockwise currents (Verbolov, 1996). A common garden comparison of growth and reproduction of Epischura with different lipid storage and of Daphnia and Cyclops sampled in the North basin at different distances from the source population may provide a direct indication of whether cosmopolitan species can sustain growth and reproduction in Baikal's oligotrophic waters at levels comparable to the endemic Epischura.

\section{Acknowledgements}

We are grateful to the Lake Baikal Dimensions of Biodiversity consortium members and the Research Vessel "Professor Treskov" crew for assistance with sample collection, to faculty and staff of Irkutsk State University for the of Bolshie Koty field station facilities and to Stephanie Hampton, Marianne Moore, Tedy Ozersky, Aruna Kilaru, Dhirendra Kumar and Bret Coggins for useful suggestions on the manuscript. This work was supported by US National Science Foundation grants 1136706 and 1136710 and Russian Ministry of Education and Science, research project GR 01201461929, Russian Science Foundation Project 14-14-00400 and Russian Federal Targeted Program 2012$1.5-14-000-1016$. 


\section{Literature cited}

Afanasyeva, E. L., 1998. Life cycle of Epischura baicalensis Sars (Copepoda, Calanoida. in Lake Baikal. Journal of marine systems 15: 351-357.

Alonzo, F. and Mayzaud, P., 1999. Spectrofluorometric quantification of neutral and polar lipids in zooplankton using Nile red. Marine Chemistry 67: 289-301

Bullejos, F.J., Carrillo, P., Gorokhova, E., Medina-Sanchez, J.M., Villar-Argaiz, M., 2014. Nucleic acid content in crustacean zooplankton: bridging metabolic and stoichiometric predictions. PLoS ONE 9: e86493.

Chícharo, M.A., Amaral, A., Morais, P., Chícharo, L., 2007. Effect of sex on ratios and concentrations of DNA and RNA in three marine species. Marine Ecology Progress Series 332: 241-245.

Chícharo, M. A., Chícharo, L., 2008. RNA:DNA ratio and other nucleic acid derived indices in marine ecology. International Journal of Molecular Sciences 9: 14531471. doi:10.3390/ijms 9081453

De Batist, M., Canals, M., Sherstyankin, P., Alekseev S. \& The INTAS Project 99-1669 Team. 2002. A new bathymetric map of Lake Baikal. http://www.lin.irk.ru/insta/index.html

Drent, R. H., Daan, S., 1980. The prudent parent: energetic adjustments in avian breeding. Ardea 68: 225-252.

Fietz, S., Kobanova, G., Izmest'eva, L., Nicklisch, A., 2005. Regional, vertical and seasonal distribution of phytoplankton and photosynthetic pigments in Lake Baikal. Journal of Plankton Research 27: 793-810.

Foley, C.J., Bradley, D.L., Hook, T.O., 2016. A review and assessment of the potential use of RNA:DNA ratios to assess the condition of entrained fish larvae. Ecological Indicators 60: 346-357.

Gusmão, F. L. M., McKinnon, A.D., 2011. Nucleic acid indices of egg production in the tropical copepod Acartia sinjiensis. Journal of Experimental Marine Biology and Ecology 396: 122-137. doi:10.1016/j.jembe.2010.10.008

Gorokhova, E., 2003. Relationships between nucleic acid levels and egg production rates in Acartia bifilosa: implications for growth assessment of copepods in situ. Marine Ecology Progress Series 262: 163-172. 
Hampton, S. E., Moore, M. V., Ozersky, T., Stanley, E. H., Polashenski, C. M., Galloway, A. W. E. 2015. Heating up a cold subject: prospects for under-ice plankton research in lakes. J. Plankton Res., 37, 277-284

Hampton S. E., Gray, D. K., Izmest'eva, L.R., Moore, M.V., Ozersky, T., 2014. The rise and fall of plankton: Long-term changes in the vertical distribution of algae and grazers in Lake Baikal, Siberia. PLoS ONE 9: e88920.

Hampton, S. E., Izmest'eva, L. R., Moore, M. V., Katz, S. L., Dennis, B., Silow, E. A., 2008. Sixty years of environmental change in the world's largest freshwater lake Lake Baikal, Siberia. Global Change Biology 14: 1947-1958. doi:10.1111/j.13652486.2008.01616.x

Holmborn, T., Dahlgren, K. Holeton, C., Hogfors, H, Gorokhova, E., 2009. Biochemical proxies for growth and metabolism in Acartia. Limnology and Oceanography: Methods 7: 785-794.

Holmborn T., Gorokhova, E., 2008. Relationships between RNA content and egg production rate in Acartia bifilosa (Copepoda, Calanoida. of different spatial and temporal origin. Marine Biology, 153, 483-491.

Izmest'eva, L.R., Silow, E. A., Litchman, E., 2011. Long-term dynamics of lake Baikal pelagic phytoplankton under climate change. Inland water biology 4: 301-307.

Izmest'eva, L.R., Moore, M.V., Hampton, S.E., Ferwerda, C. J., Gray, D.K., Woo, K.H., Pislegina, H.V., Krashchuk, L.S., Simaraeva S.V., Silow, E.A. Lake-wide physical and biological trends associated with warming in Lake Baikal. J. Great Lakes Research 42: 6-17.

Jönsson, K. I., 1997. Capital and income breeding as alternative tactics of resource use in reproduction. Oikos 78:57-66.

Kaplan, L.A.E., Leamon, J., Crivello, J.F., 2001. The development of a rapid and sensitive, high-through-put protocol for RNA : DNA ratio analysis. J. Aquatic Animal Health, 13, 276-279.

Katz, S. L., Izmest'eva, L. R., Hampton, S, E., Ozersky, T., Shchapov, K., Moore, M. V., ; Shimaraeva, S. V., Silow, E. A., 2015. The "Melosira years" of Lake Baikal: Winter 
environmental conditions at ice onset predict under-ice algal blooms in spring. Limnology and Oceanography, 60, 1950-1964.

Kenward, M., Roger, J., 1997. Small sample inference for fixed effects from Restricted Maximum Likelihood. Biometrics 53, 983-997.

Kozhov, M.M., 1963. Lake Baikal and its life. Dr. W. Junk, The Hague, Netherlands. Kozhova, O.M., Izmest'eva, L. R., 1998. Lake Baikal: Evolution and biodiversity. Backhuys Publ., Leiden, Netherlands.

Mackay, A. W., Ryves, D. B., Morley, D. W., Jewson, D. H., Rioual, P., 2006. Assessing the vulnerability of endemic diatom species in Lake Baikal to predicted future climate change: A multivariate approach. Global Change Biology 12: 2297-2315. McGinty E.L., Smith-Keune, C., Jerry, D. R., 2008. A high through-put protocol for quantifying nucleic acids in individual microcrustaceans using new generation RNA and DNA specific dyes. Journal of Shellfish Research 27: 449-455.

Melnik, N. G., Sheveleva, N. G., Pomazkova, G. I., 1998. Distribution of planktonic copepods of Lake Baikal. Journal of Marine Systems 15: 149-15

Moore M. V., Hampton, S. E., Izmest'eva, L. R., Silow, E. A., Peshkova, E. V., Pavlov B. K., 2009. Climate change and the world's "Sacred Sea" - Lake Baikal, Siberia. BioScience 59: 405-417.

Ning J., Li, C., Yang, G., Wan A.Y., Sun, S., 2013. Use of RNA:DNA ratios to evaluate the condition and growth of the copepod Calanus sinicus in the Southern Yellow Sea. Deep-Sea Research Part II - Topical Studies In Oceanography 97: SI 109-116.

Paulsen, M., Clemmesen, C., Malzahn, A.M., 2014. Essential fatty acid (docosahexaenoic acid, DHA) availability affects growth of larval herring in the field. Marine Biol. 161: 239-244.

Peters, J., Diekmann, R., Clemmesen, C., Hagen, W., 2015. Lipids as a proxy for larval starvation and feeding condition in small pelagic fish: a field approach on matchmismatch effects on Baltic sprat. Marine Ecology Progress Series 531: 277-292.

Roff, D. A. 1992. The evolution of life histories. Theory and analysis. Chapman and Hall, New York, New York, USA.

SAS Institute 2010. JMP 10 User Manual. SAS Institute, Cary, North Carolina. 
Sars, G. O., 1900. On Epischura baikalensis, a new calanoid from Baikal Lake. Annuaire du Musée Zoologique, L'Académie Impériale des Sciences de St.-Pétersbourg, V, 226-240.

Sainmont, J, Andersen, K.H., Varpe, Ø., Visser, A.W., 2014. Capital versus income breeding in a seasonal environment. Amer. Naturalist 184: 466-476. doi: $10.1086 / 677926$.

Saiz, E., Calbet, A., Fara, A., Berdalet, E., 1998. RNA content of copepods as a tool for determining adult growth rates in the field. Limnology and Oceanography 43: 465470.

Shimaraev, M.N., Troitskaya, Y.S., Gnatovsky, R.Y., 2009. Modern climate changes and deep water temperature of Lake Baikal. Doklady Earth Sciences, 427, 804-8.

Shimaraev, M.N., Domysheva, V.M., 2013. Trends in hydrological and hydrochemical processes in Lake Baikal under conditions of modern climate change. In: Goldman, C.R., Kumagai, M., Robarts, R.D. (Eds.), Climatic Change and Global Warming of InlandWaters. John Wiley and Sons, Ltd., Chichester, pp. 43-66.

Speekmann, C.L., Nunez, B. S., Buskey, E. J., 2007. Measuring RNA:DNA ratios in individual Acartia tonsa (Copepoda). Marine Biology 151: 759-766.

Stearns, S. C., 1992. The evolution of life histories: theory and analysis. Oxford University Press, Oxford, UK.

Stephens, P. A., Boyd, I. L., McNamara, J. M., Houston, A. I., 2009. Capital breeding and income breeding: their meaning, measurement, and worth. Ecology 90: 2057-2067.

Stephens, P.A., Houston, A.I., Harding, K.C., Boyd, I.L., McNamara, J. M., 2014. Capital and income breeding: the role of food supply. Ecology 95: 882-896.

Straskrabova, V., Izmest'yeva, L.R., Maksimova, E. A., Fietz, S., Nedoma, J., Borovec, J., Kobanova, G. I., Shchetinina, E. V., Pislegina, E.V., 2005. Primary production and microbial activity in the euphotic zone of Lake Baikal (Southern Basin) during late winter. Global and planetary change 46: 57-73.

Tang, F., Minch, T., Dinning, K., Martyniuk, C.J., Kilada, R., Rochette, R., 2015. Size-atage and body condition of juvenile American lobsters (Homarus americanus) living on cobble and mud in a mixed-bottom embayment in the Bay of Fundy. Marine Biology 162: 69-79. 
Varpe, Ø, Jorgensen, C., Tarling, G., Fiksen, O., 2009. The adaptive value of energy storage and capital breeding in seasonal environments. Oikos 118: 363-370. DOI: 10.1111/j.1600-0706.2008.17036.x

Verbolov, V.I., 1996. Currents and water exchange in Baikal. Vodnye Resursy 23: 413423. (In Russian).

Vrede T., Persson, J., Aronsenl, G. , 2002. The influence of food quality ( P : C ratio ) on RNA : DNA ratio and somatic growth rate of Daphnia. Limnology and Oceanography 47: 487-494.

Wagner M. M., Campbell, R. G., Boudreau, C. A., Durbin, E. G., 2001. Nucleic acids and growth of Calanus finmarchicus in the laboratory under different food and temperature conditions. Marine Ecology Progress Series 221: 185-197.

Wagner M., Durbin, E., Buckley, L.,1998. RNA:DNA ratios as indicators of nutritional condition in the copepod Calanus finmarchicus. Marine Ecology Progress Series 162: 173-181. doi:10.3354/meps 162173 


\section{Tables}

Table 1. Nested ANOVA of the differences between regions (NC vs. SM) in average lipid scores and square root-transformed RNA:DNA ratio (stations nested within regions).

\begin{tabular}{lllll}
\hline Source & DF & SS & F & P \\
\hline Region & 1 & \multicolumn{2}{c}{ Lipid score } \\
Station & 8 & 1.34 & 1.86 & $>0.1$ \\
Error & 95 & 26.55 & 4.61 & $8.8 \times 10^{-5}$ \\
\hline \multirow{5}{*}{ Region } & 1 & 68.33 & & \\
Station & 8 & RNA:DNA Ratio & 0.002 \\
Error & 94 & 1.38 & 10.1 & $>0.1$ \\
\hline
\end{tabular}


Table 2. Heterogeneity of slopes analysis of the effect of lipid score on individuals' square root-transformed RNA:DNA ratio in two regions (NC vs. SM).

\begin{tabular}{lllll}
\hline Source & DF & SS & F & P \\
\hline Lipid score & 1 & 0.41 & 3.24 & 0.07 \\
Region & 1 & 1.16 & 9.26 & 0.003 \\
Lipid score X & 1 & 1.22 & 9.71 & 0.0024 \\
Region & & & & \\
Error & 100 & 12.57 & & \\
\hline
\end{tabular}


Table 3. Two-way ANOVA of the effects of feeding conditions / temperature exposure and ovary development or lipid content score on square root-transformed RNA:DNA ratio. Data from wild-caught individuals are included as controls in both experiments. Note synthetic denominator degrees of freedom in all tests except the test of lipids scores in the feeding/fasting experiment, where the REML procedure converged on using pure residual d.f.'s as the denominator.

\begin{tabular}{|c|c|c|c|c|}
\hline Source & DF & DFDen & $\mathrm{F}$ & $\mathrm{P}$ \\
\hline \multicolumn{5}{|c|}{ Feeding/fasting experiment: Effect of lipids score } \\
\hline Feeding & 2 & 101 & 4.16 & 0.018 \\
\hline Lipids & 2 & 101 & 0.09 & 0.91 \\
\hline Feeding*Lipids & 4 & 101 & 2.86 & 0.027 \\
\hline \multicolumn{5}{|c|}{ Feeding/fasting experiment: Effect of ovaries score } \\
\hline Feeding & 2 & 5.49 & 0.76 & 0.51 \\
\hline Ovaries & 2 & 11.28 & 17.77 & 0.0003 \\
\hline Feeding*Ovaries & 4 & 11.4 & 2.34 & 0.118 \\
\hline \multicolumn{5}{|c|}{ Temperature experiment: Effect of lipids score } \\
\hline \multicolumn{5}{|c|}{ Lipids score } \\
\hline Temperature & 3 & 8.92 & 6.26 & 0.014 \\
\hline Lipids & 2 & 6.63 & 4.54 & 0.057 \\
\hline Temperature*Lipids & 6 & 5.86 & 0.55 & 0.76 \\
\hline \multicolumn{5}{|c|}{ Temperature experiment: Effect of ovaries score } \\
\hline Temperature & 3 & 11.4 & 2.65 & 0.099 \\
\hline Ovaries & 2 & 16.01 & 11.51 & 0.0008 \\
\hline Temperature*Ovaries & 6 & 15.63 & 1 & 0.46 \\
\hline
\end{tabular}




\section{Figure legends}

Figure 1. A: Map of Lake Baikal with locations of sampling stations. Modified from De Batist et al., 2002 / http://www.lin.irk.ru/insta/index.html. B: separation of warmer, more productive South basin and Maloe More stations (open symbols ) from colder, oligotrophic North and Central basins stations (filled symbols ) on the plane of the first two principal components based on temperature, chlorophyll and phytoplankton parameters.

Figure 2. Females of Epischura baikalensis with different degrees of lipid content (A-D) and ovaries development (E-H). Lipid scores, lateral view: A -“0” (no large lipid vesicles visible); B - "1” (lipid vesicles visible but not touching); C - "2" (lipid vesicles are touching each other and occupy about $1 / 2$ of the cephalothorax length); D - " 3 " (a large lipid vesicle occupying about $2 / 3$ of the cephalothorax length). Ovaries, dorsal view: E “0” (no visible ovaries); F - "1" (ovaries detectable as nearly transparent elongate structures); G - "2" (ovaries clearly visible as dark structures occupying over $3 / 4$ of the cephalothorax length). The individual in D has lipid score 1 and ovary score 2.

Figure 3. Relationships between temperature (in situ and long-term), phytoplankton cell counts, Epischura lipid content and RNA:DNA ratio. A: Phytoplankton cells counts (picoplankton excluded) vs. temperature at $15 \mathrm{~m}$ depth. B: Epischura lipids content per wet weight vs. phytoplankton cells count at the same station. C: RNA:DNA ratio vs. long- 
term temperature data. D: RNA:DNA ratio vs. phytoplankton cells count. All regression lines shown are linear regressions with $\mathrm{P}<0.01$.

Figure 4. Means and standard errors of square root transformed RNA:DNA ratio in individuals with lipid score 0-3 sampled in South basin and Maloe More (open symbols, SM) and from North and Central basins (filled symbols, NC). Solid line: linear regression, $\mathrm{P}<0.01$; dashed line: linear regression with $\mathrm{P}>0.5$.

Figure 5. Means and standard errors of RNA:DNA ratio in fasting (A, C) and temperature (B, D) experiments (with wild-caught individuals as a common control). A, B: RNA:DNA ratio in individuals categorized by their lipid score. C, D: RNA:DNA ratio in individuals categorized by their ovary development score. Letters indicate values significantly different by Tukey test $(\mathrm{P}<0.05)$ : values sharing letters are not significantly different. 
Fig. 1
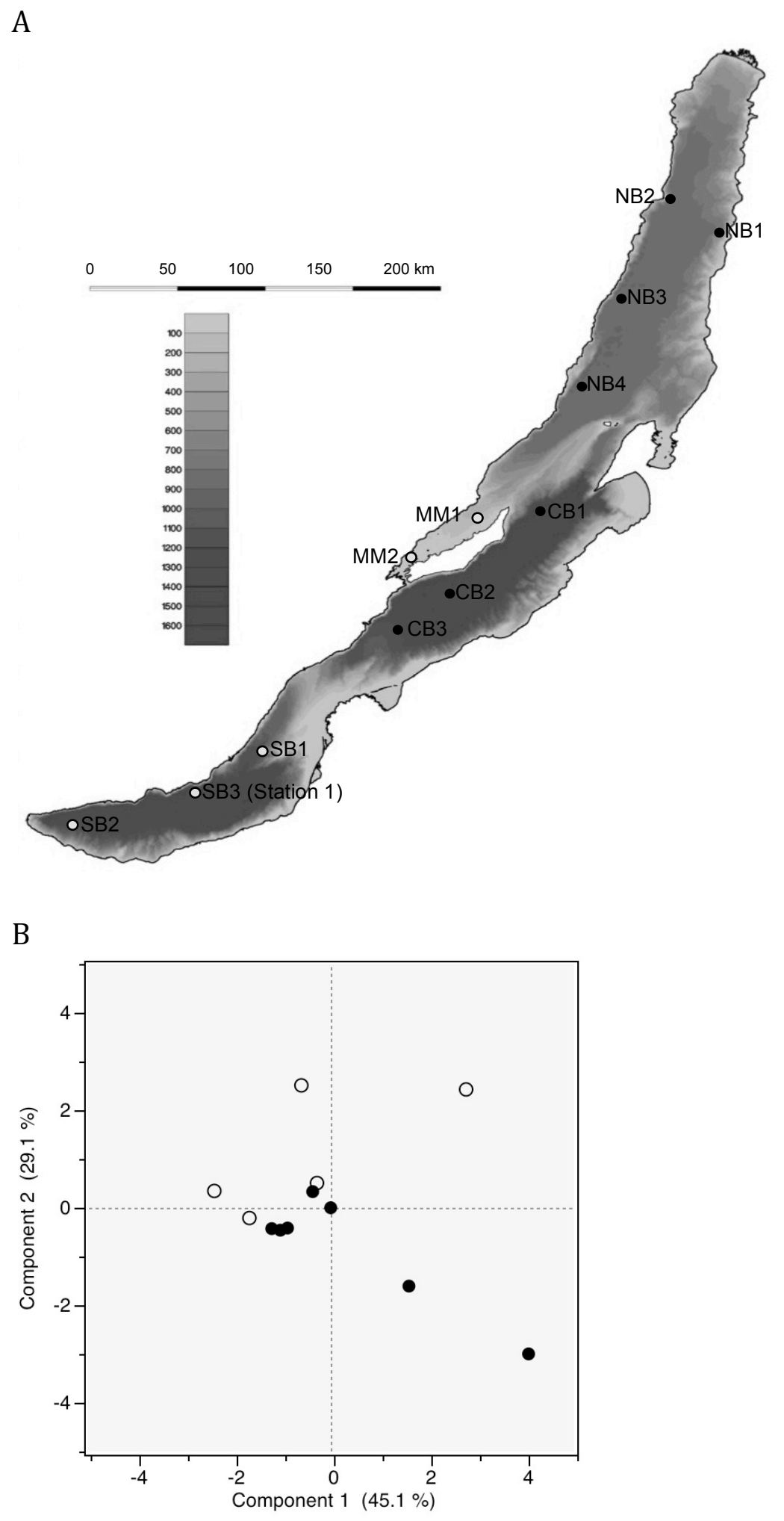
Fig. 2

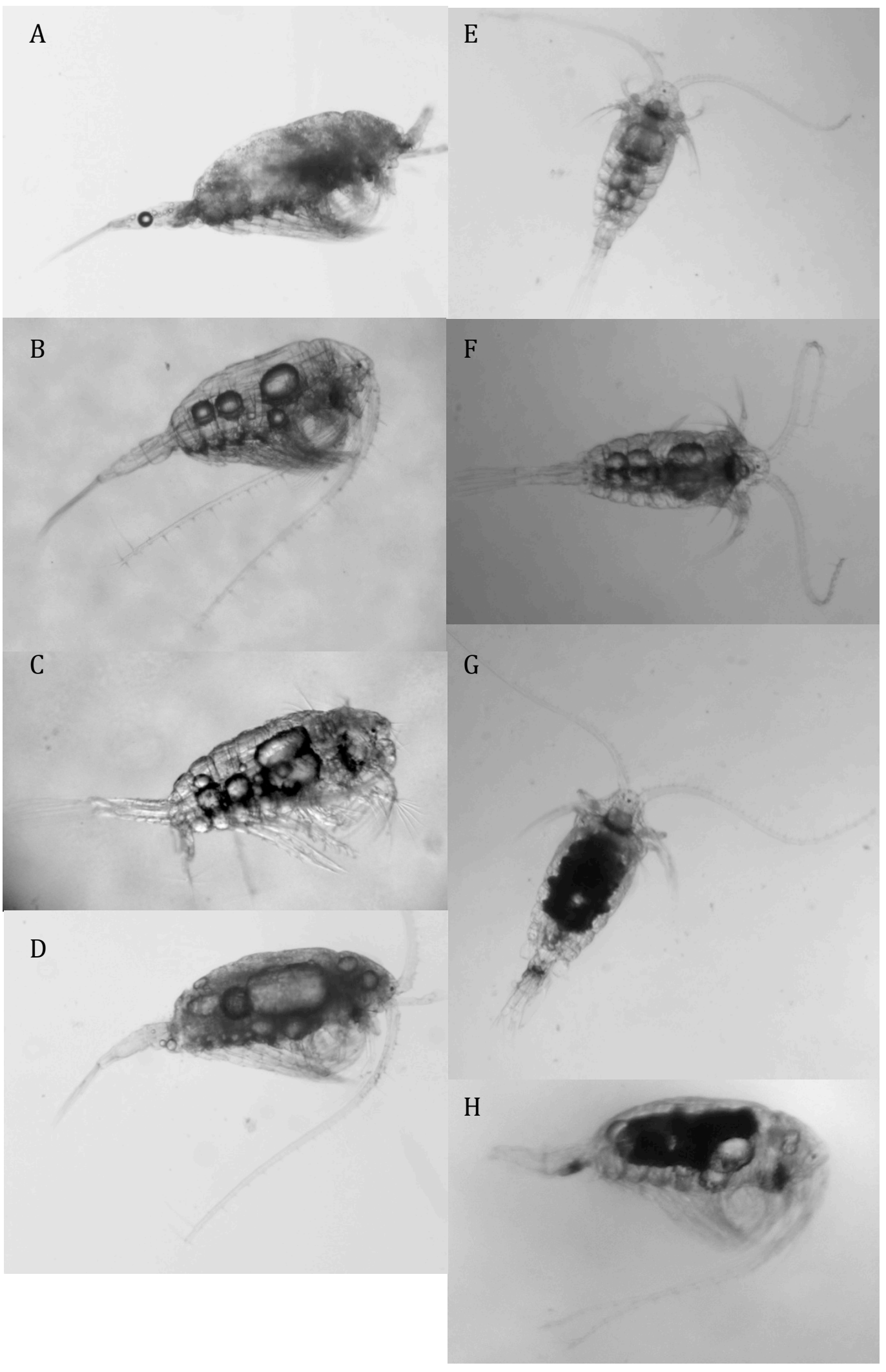


Fig. 3
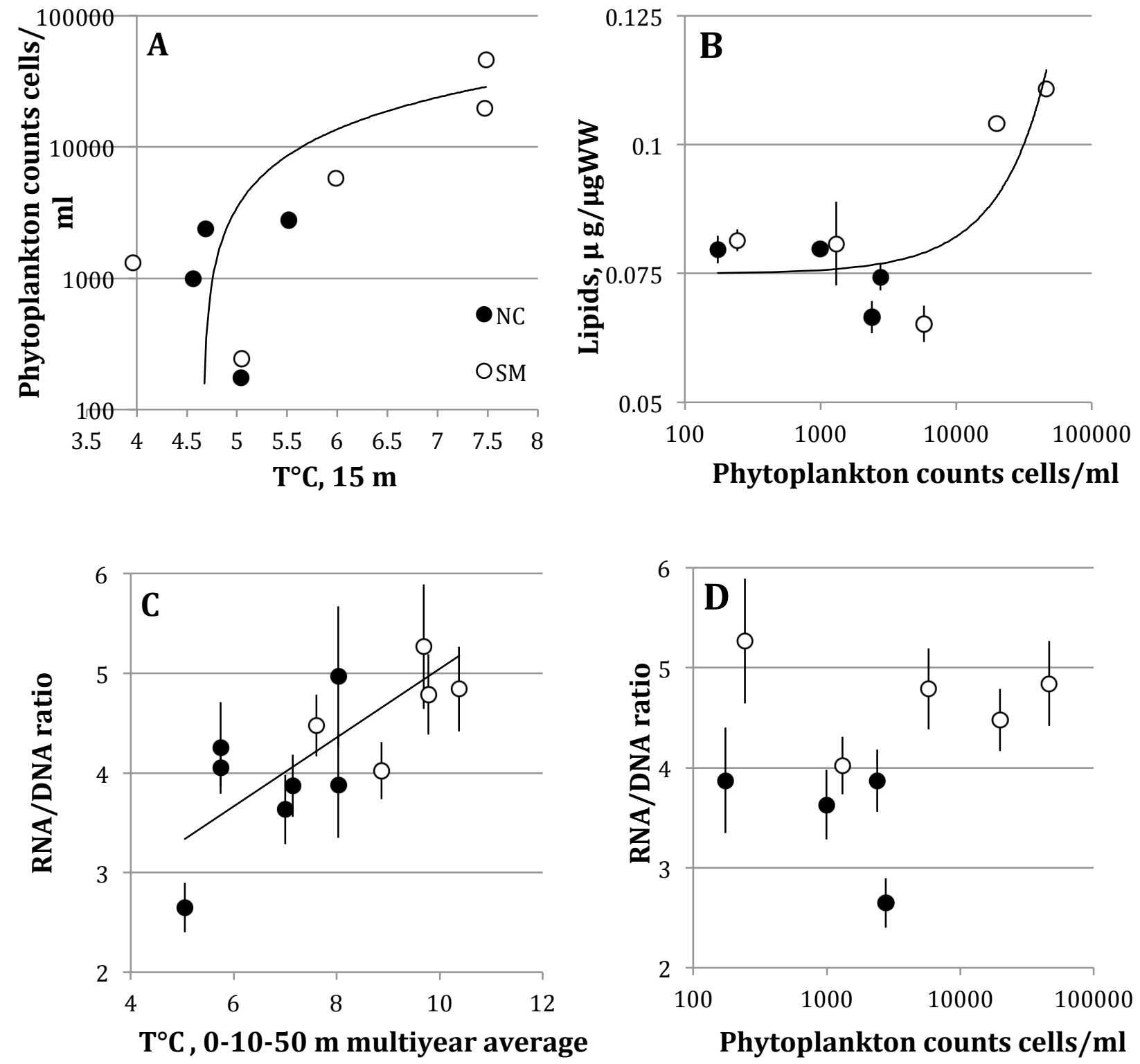
Fig. 4.

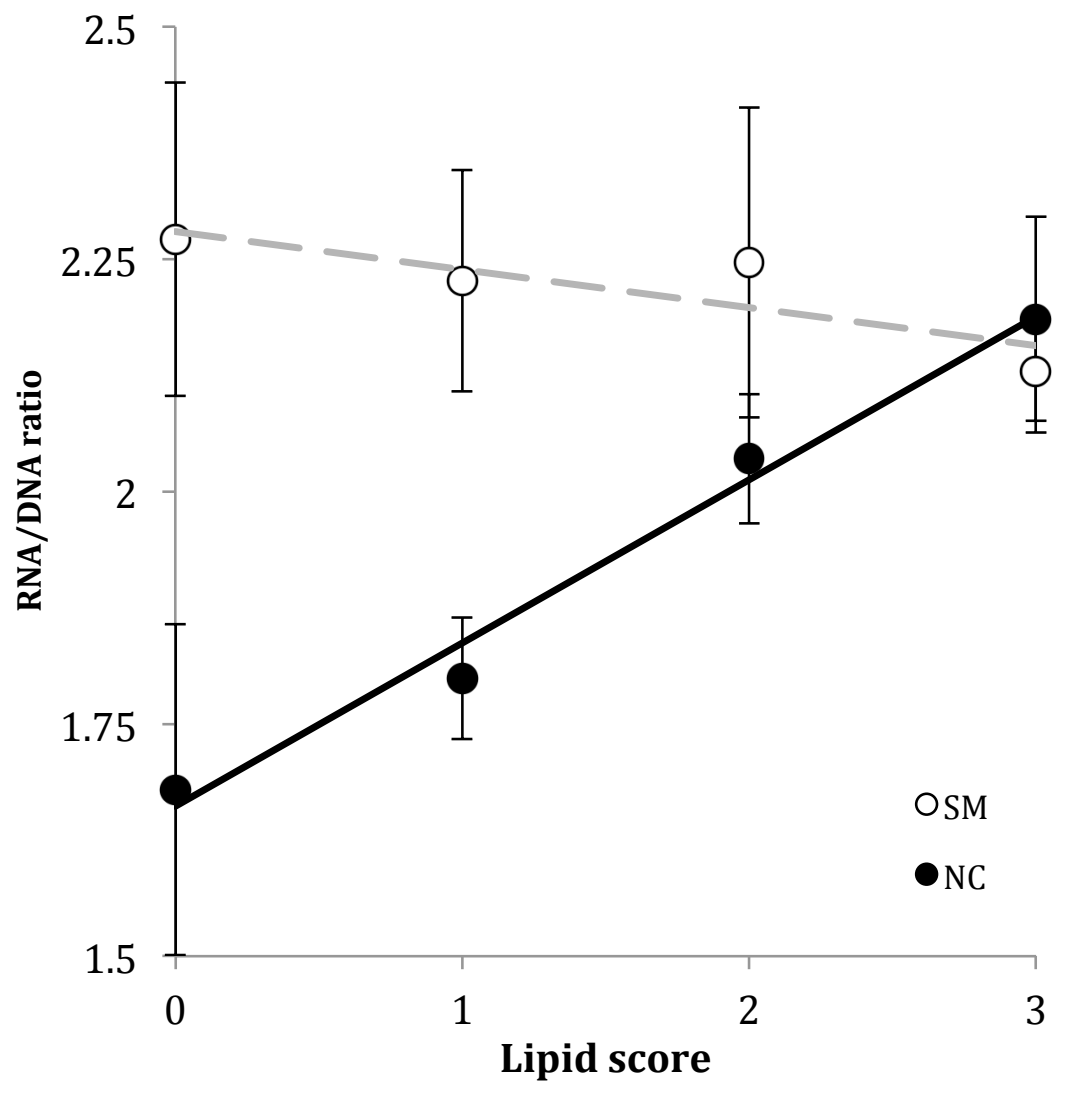


Fig. 5
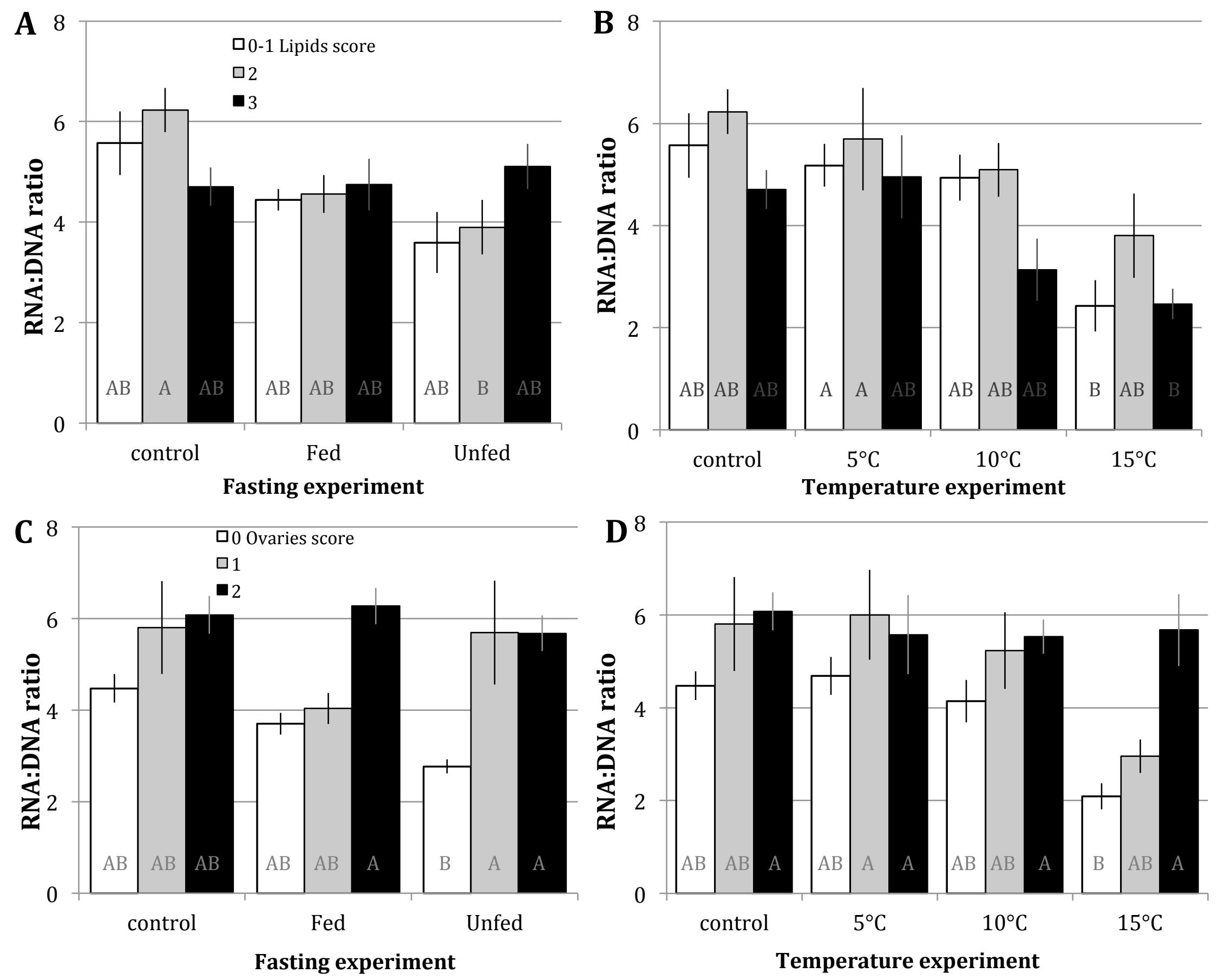